\title{
Essential habitat for sardine juveniles in Iberian waters
}

\author{
Sílvia Rodríguez-Climent, Maria Manuel Angélico, Vítor Marques, Paulo Oliveira, \\ Laura Wise, Alexandra Silva
}

Instituto Português do Mar e da Atmosfera (IPMA), Rua Alfredo Magalhães Ramalho, 6, 1495-006 Lisboa. Portugal. (SR-C) (Corresponding author) E-mail: silviarodriguezcliment@ gmail.com. ORCID iD: http://orcid.org/0000-0001-7760-0459 (MMA) E-mail: mmangelico@ipma.pt. ORCID iD: http://orcid.org/0000-0003-1385-5131

(VM) E-mail: vmarques@ipma.pt. ORCID iD: http://orcid.org/0000-0003-4676-595X

(PO) E-mail: pboliveira@ipma.pt. ORCID iD: http://orcid.org/0000-0001-6838-7377

(LW) E-mail: lwise@ipma.pt. ORCID iD: http://orcid.org//0000-0002-7819-7371

(AS) E-mail: asilva@ipma.pt. ORCID iD: http://orcid.org/0000-0002-2950-1429

\begin{abstract}
Summary: In a period when the Iberian sardine stock abundance is at its historical minimum, knowledge of the sardine juvenile's distribution is crucial for the development of fishery management strategies. Generalized additive models were used to relate juvenile sardine presence with geographical variables and spawning grounds (egg abundance) and to model juvenile abundance with the concurrent environmental conditions. Three core areas of juvenile distribution were identified: the Northern Portuguese shelf (centred off Aveiro), the coastal region in the vicinity of the Tagus estuary, and the eastern Gulf of Cadiz. Spatial differences in the relationship between juvenile presence and egg abundances suggest that essential juvenile habitat might partially differ from the prevailing spawning grounds. Models also depicted significant relationships between juvenile abundance, temperature and geographical variables in combination with salinity in the west and with zooplankton in the south. Results indicate that the sardine juvenile distribution along the Iberian Peninsula waters are an outcome of a combination of dynamic processes occurring early in life, such as egg and larva retention, reduced mortality and favourable feeding grounds for both larvae and juveniles.
\end{abstract}

Keywords: Portuguese coast; Gulf of Cadiz; acoustic survey; fish habitat; Sardina pilchardus; juveniles; fisheries management.

\section{Hábitat esencial para los juveniles de sardina en aguas Ibéricas}

Resumen: En un periodo de mínimo histórico para el stock de sardina ibérica, el conocimiento de la distribución de los juveniles de sardina resulta crucial para el desarrollo de estrategias de gestión pesquera. Se usaron modelos aditivos generalizados para relacionar la presencia de los juveniles de sardina con las variables geográficas y las principales zonas de desove (abundancia de huevos) y a su vez para relacionar la abundancia de los juveniles con las condiciones ambientales adyacentes. Se identificaron tres zonas centrales: la plataforma norte portuguesa (centrada enfrente de la localidad de Aveiro), la zona costera próxima al estuario del Tajo y la parte este del golfo de Cádiz. Las diferencias espaciales encontradas en la relación entre la presencia de juveniles y la abundancia de huevos sugieren que el hábitat esencial de los juveniles puede diferir parcialmente de las zonas de desove existentes. Los modelos también señalaron relaciones significativas entre la abundancia de juveniles, la temperatura, y las variables geográficas combinadas con la salinidad en el oeste y con el zooplancton en el sur. Los resultados indican que la distribución de los juveniles de sardina a lo largo de las aguas de la Península Ibérica resulta de la combinación de procesos dinámicos que se dan en edades tempranas, cómo la retención de huevos y larvas, una mortalidad reducida y zonas de nutrición con condiciones favorables tanto para larvas cómo para juveniles.

Palabras clave: costa portuguesa; golfo de Cádiz; campaña acústica; hábitat de peces; Sardina pilchardus; juveniles; gestión pesquera.

Citation/Como citar este artículo: Rodríguez-Climent S., Angélico M.M., Marques V., Oliveira P., Wise L., Silva A. 2017. Essential habitat for sardine juveniles in Iberian waters. Sci. Mar. 81(3):351-360. doi: http://dx.doi.org/10.3989/scimar.04554.07A

Editor: V.D. Valavanis.

Received: September 23, 2016. Accepted: April 10, 2017. Published: June 30, 2017.

Copyright: () 2017 CSIC. This is an open-access article distributed under the terms of the Creative Commons Attribution (CC-by) Spain 3.0 License. 


\section{INTRODUCTION}

Essential fish habitat $(\mathrm{EFH})$ is the high-quality area where a species feeds, grows, matures and spawns during its ontogenic development (Council Directive 92/43/ EEC). In ecosystem-based fishery management (Levin and Stunz 2005), it is crucial to identify which habitat(s) a certain fish species uses during its different life stages, and the sustainability of fish populations necessarily involves the preservation of EFH (Valavanis et al. 2008).

Preserving EFH for juveniles is of special importance in small pelagic exploited species such as sardine (Sardina pilchardus [Walbaum, 1972]), whose population abundance depends heavily on incoming recruitment each year. Sardine is a small eurythermic and euryhaline clupeoid, distributed in the northeastern Atlantic Ocean from the southern Celtic Sea and the North Sea to Senegal, and across the western and northern Mediterranean Sea (Parrish et al. 1989). It generally inhabits waters with temperatures ranging from 8 to $24^{\circ} \mathrm{C}$ and salinities ranging from 30 to $38 \mathrm{psu}$ (Petitgas et al. 2006). Sardine populations support important fisheries across their distribution area (Whitehead 1985). In Iberian Peninsula waters (ICES areas 9a and 8c), both Portuguese and Spanish purse seine fleets target sardine. In the past decade, the abundance of sardine has decreased abruptly (2.6-fold from 2005 to 2009) and is presently at the lowest historical level (ICES 2016). Low abundance and catch regulations lead to a 2.2-fold decrease in landings from 2013 to 2015 (ICES 2016).

In small pelagic species, juveniles are more vulnerable to environmental changes (Giannoulaki et al. 2011). In the western coast of the Iberian Peninsula, the potential habitat for adult sardine has been described to be driven by a particular set of environmental conditions: high chlorophyll $a$ concentrations in association with low salinities and both high or low temperatures (i.e. freshwater enrichment), or with low temperatures and average salinities (i.e. coastal upwelling waters) (Zwolinski et al. 2010). Spawning areas have also been described for this area (Bernal et al. 2007), but there is limited information regarding the distribution of sardine juveniles (Marques 2005). The only information for this area is their regular presence on the northern Portuguese coastal shelf due to the proximity of the Douro, Ria de Aveiro, Tejo and Sado estuaries (Silva et al. 2009).

Under the hypothesis that similar conditions to the ones described to localize eggs and adults will drive juvenile dynamics off the Portuguese coast and the Gulf of Cadiz, this work focuses on two aspects: (i) is presence of sardine juveniles related to their egg abundance (as a proxy for spawning grounds)? and (ii) which of the main environmental factors already described to influence adult sardine distribution is associated with their spatial distribution?

\section{MATERIALS AND METHODS}

\section{Acoustic sampling}

Acoustic data were obtained during six acoustic surveys conducted in spring (2005-2010; Table 1).

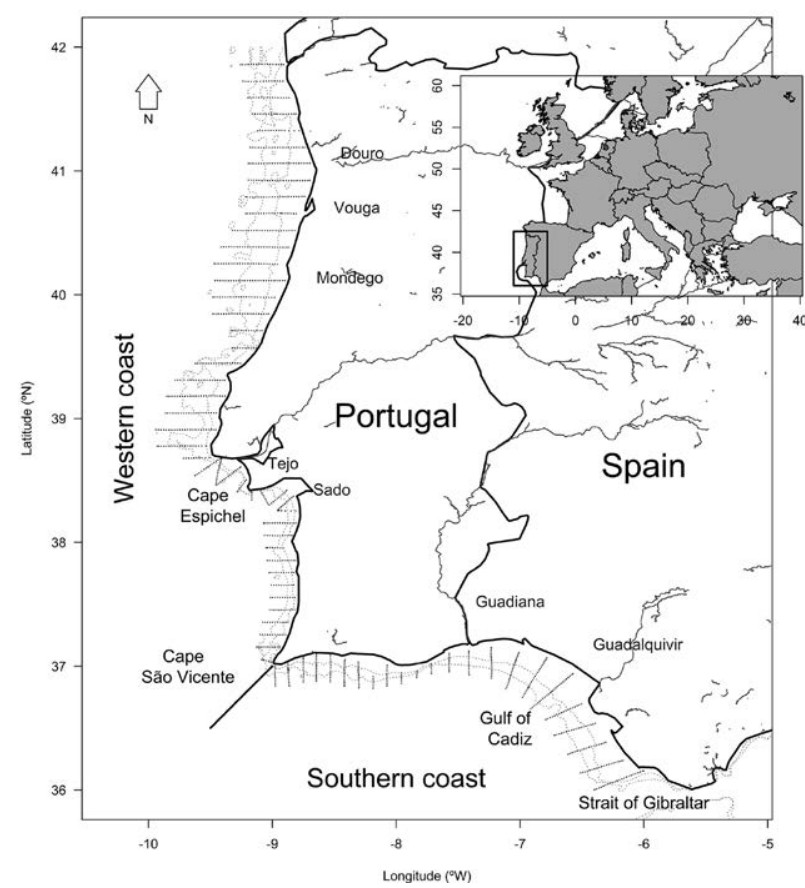

Fig. 1. - Map of the sampled area with acoustic transects. Dashed lines show the 50 and $100 \mathrm{~m}$ bathymetry. The black line represents the separation between the western and the southern areas.

The acoustic surveys were carried out onboard the R/V Noruega along predefined parallel transects perpendicular to bathymetry from 20 to $200 \mathrm{~m}$ depth with 8 nautical miles $(\mathrm{nm})$ inter-transect distance. The same sampling design was followed in all years along the Portuguese coast and Gulf of Cadiz (Fig. 1). Surveying was limited to daylight following the methodology described in ICES (2016). Echo integration was carried out with a Simrad $38 \mathrm{kHz}$ EK500 scientific echosounder. The echosounder was calibrated before each survey by means of a cupper sphere, according to standard procedure (Foote et al. 1987). Acoustic fish energy data were recorded and integrated with MOVIES+ software (Weill et al. 1993). Echo integration was performed from 20 $\mathrm{cm}$ above the seabed (prior, echogram bottom was manually corrected) to $3 \mathrm{~m}$ below the transducer, along 1-nm elementary distance sampling units (ESDU). Fish samples were collected with pelagic and bottom trawls. Trawl samples were used to assist in species identification to split the acoustic energy within species and by length. For each trawl, a sample of approximately $100 \mathrm{~kg}$ of fish was taken and sorted by species. For sardine, a sub-sample of 100 individuals was taken and their total length (TL) and weight (W) were measured. In this study, juveniles were considered to be individuals with $T L \leq 16.0 \mathrm{~cm}$ (Silva et al. 2006). Sardine age-length keys show that individuals with TL $\leq 16.0 \mathrm{~cm}$ broadly represent the recruiting year-class in spring surveys (age-1 individuals). Since sardine length at which $50 \%$ of the fish are mature $\left(\mathrm{L}_{50}\right)$ is around $14.0 \mathrm{~cm}$ in the study areas (Silva et al. 2006), a small proportion of young adults are also included. 

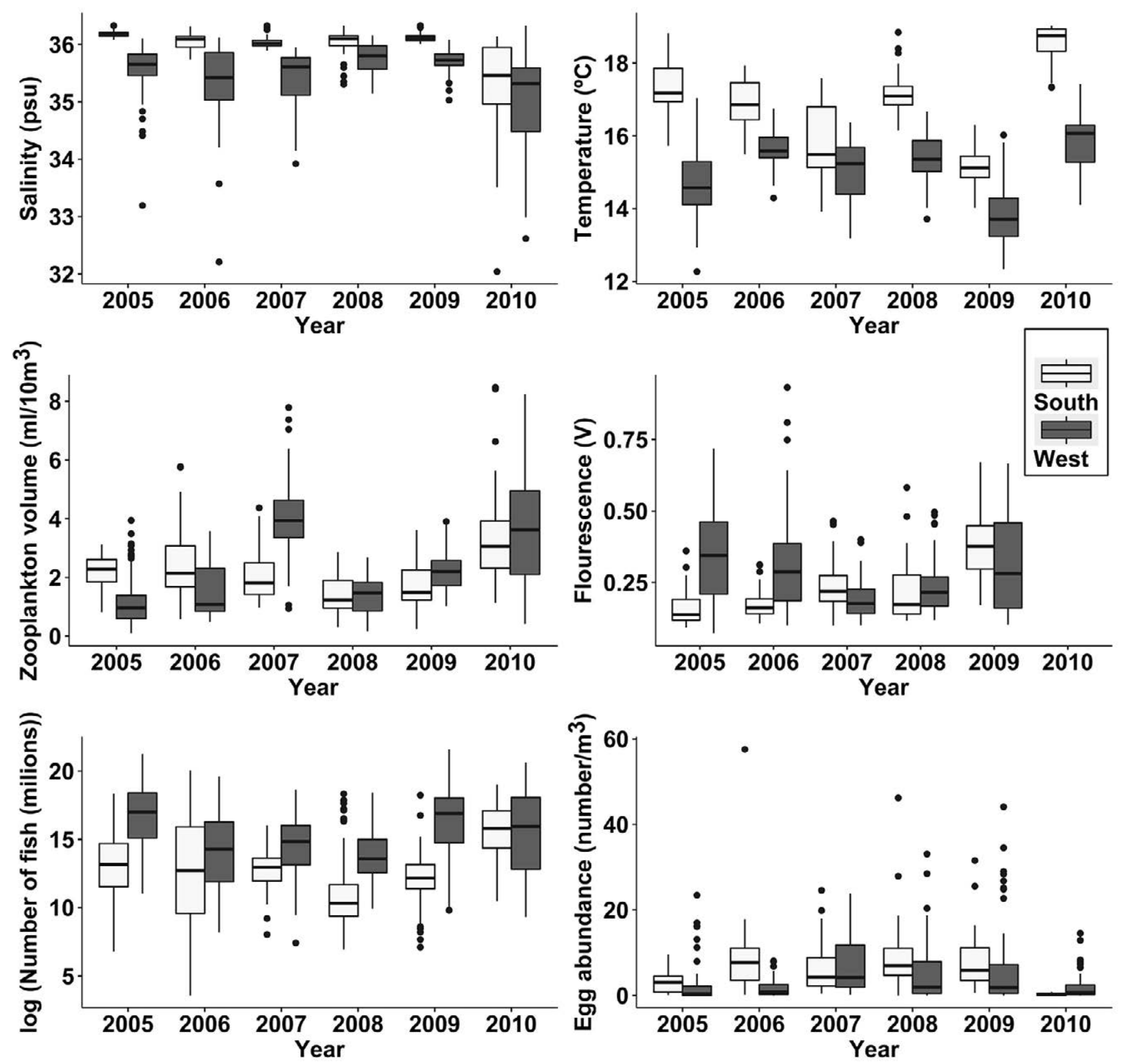

Fig. 2. - Boxplots showing the mean values for the environmental variables (salinity, temperature, zooplankton volume and fluorescence), the abundance of fish (in number) and the egg abundance per year and area. Lower and upper boundaries represent the $25 \%$ and $75 \%$ quantiles and the vertical lines represent the range of the data.

\section{In situ environmental data}

Along the acoustic transects, a Continuous Underway Fish Egg Sampler (CUFES, mesh $335 \mu \mathrm{m}$ ) was used for plankton surveying. Water was pumped at a rate of approximately $600 \mathrm{~L} \mathrm{~min}^{-1}$ from a depth of $3 \mathrm{~m}$. Samples were collected every $3 \mathrm{~nm}$ to monitor sardine egg abundance (number of eggs per water filtered $\mathrm{m}^{-3}$ ). Total zooplankton volume $\left(\mathrm{ml} / 10 \mathrm{~m}^{3}\right)$ was measured through displacement volume. Concurrently, sea surface temperature $\left({ }^{\circ} \mathrm{C}\right)$, salinity (psu) and fluorescence $(\mathrm{V}$; a proxy for chlorophyll $a$ ) were measured using high-resolution probes coupled to the CUFES system. Fluorescence was not recorded in 2010 due to sensor malfunction. As a result, this year was included in the boxplots (Fig. 2), but not considered in the models.

\section{Data analysis}

Echograms were screened to remove noise from bubbles, double echoes and when necessary plankton (Simmonds and McLennan 2005). Species acoustic energy was attributed by visual inspection and supported by fishing trawls. Acoustic samples for sardine were obtained by performing echo integration along $1 \mathrm{~nm}$ ESDUs. The minimum volume scattering strength $(\mathrm{Sv})$ integration threshold for fish was set at $-60 \mathrm{~dB}$, which is the value used for echo integration of sardine for assessment purposes. Once the energy was attributed to sardine, adults $(\mathrm{TL}>16 \mathrm{~cm})$ and juveniles (TL $\leq 16$ $\mathrm{cm})$ were separated and treated as different groups. Estimates of sardine juvenile abundance (in number and biomass) were calculated following the procedures 
described in Simmonds and MacLennan (2005) and implemented in the "EchoR" package (Doray 2013) for R (R Development Core Team 2011). Based on sardine growth (Silva et al. 2006), we assumed sardine juveniles observed each year to be survivors of eggs spawned the year before. Therefore, estimates of sardine juvenile abundance were made with the explanatory variables of year $i$ with the corresponding variable egg abundance of the previous year (year $i-1$ ).

Two areas were defined a priori on the basis of consistent hydrographic and biological domains. The western area $\left(37-42^{\circ} \mathrm{N} ; 9-10^{\circ} \mathrm{W}\right)$ that extends from the northern Portuguese-Spanish border to Cape São Vicente (Fig. 1) is enriched in winter by the runoff of several rivers (Minho, Douro, Tejo and Sado) and strong upwelling episodes that last from spring to early autumn (April to September). These features ensure high nutrient availability and relatively high primary productivity throughout the year (Peliz and Fiúza 1999). The southern area $\left(35-37^{\circ} \mathrm{N} ; 6-9^{\circ} \mathrm{W}\right)$ is delimited in the west by Cape São Vicente and in the east by Cape Trafalgar (Fig. 1). In Cape São Vicente, the coastline orientation changes ca. $90^{\circ}$, with implications for coastal oceanography: while the upwelling regime is strong and persistent in the north due to the prevalence of northerly winds, it is weak and intermittent in the south (Relvas and Barton 2002).

Environmental variables (temperature, salinity, fluorescence), egg abundance and number of fish were averaged on a common regular grid with $0.25^{\circ}$ spaced nodes following the gridding methodology of the Working Group on Acoustic and Egg Surveys for Sardine and Anchovy in ICES Areas 7, 8 and 9 (WGACEGG) (ICES 2016). To randomize grid origin, a small procedure of four steps is applied: (i) 200 grids are generated, each with a different origin, (ii) data are averaged for each one, (iii) all grids are superposed with the same origin, and finally (iv) the mean in each cell is calculated over all the grids (ICES 2016).

To reduce skewness of raw data, egg and juvenile abundance were square root-transformed, and zooplankton volume, salinity and fluorescence were logtransformed. All variables were right-skewed apart from salinity, which was left-skewed. Thus, prior to log-transformation, salinity values were transformed $(1+$ maximum salinity) to obtain right-skewed distributions. The consequent inversion of the salinity scale needs to be taken into account in the interpretation of results.

Generalized additive models (GAMs) with a binomial distribution and a logit-link function were used to test the relationship of sardine juvenile presence with geographical variables (latitude and longitude) and egg abundance (analysis restricted to the period 20062010). The initial model considered the additive effect of a bivariate anisotropic smoother of latitude and longitude and a univariate smoother of egg abundance. GAMs with a negative binomial distribution and a loglink function were used to test the relationships of sardine juvenile abundance (in numbers) with geographical variables, environmental variables and zooplankton volume (analysis restricted to the period 2005-2009, when all variables were available). The initial model considered additive smooth effects of all variables. After finding the best model with environmental variables only, we tested whether the addition of geographic variables (latitude/longitude) resulted in a significant model improvement. GAMs were built separately for each area and were all fitted using the "mgcv" package (Wood 2006) for R (R Development Core Team 2011). Model selection was carried out by likelihood ratio tests (LRT) using the chi-square statistic. When the number of effective degrees of freedom of smooth terms was close to one, smoothers were replaced by linear coefficients independently of the results of LRT. Residual analyses were used to check normality and variance homogeneity of the response variable (Wood 2006). The presence of spatial autocorrelation in juvenile abundance was checked by examining variograms of model residuals and plots of residuals against geographic variables (Wood 2006).

\section{RESULTS}

Data from 413 acoustic transects and 239 trawl stations were collected during 177 effective survey days (Table 1). On average, sardine adults were present at $65 \%$ of the trawl stations and juveniles at $38 \%$. In the last year of the series, the number of fishing hauls decreased due to the lower detection of adult sardine shoals. Juvenile abundance varied substantially over the years, showing a sharp decrease from 19211 million individuals in 2005 (the highest abundance observed) to 665 million individuals in 2007 and a small increase thereafter, reaching 4901 million individuals in 2010 (Table 1 and Fig. 2).

Sardine juveniles were consistently more abundant on the western coast, and the years of higher abundance in this area $(2005,2009)$ were always followed by years of higher values of sardine juvenile abundance in the south (2006, 2010; Fig. 2 and supplementary material). Three core areas of juvenile distribution were found: the northern Portuguese shelf (centred off Aveiro), the coastal region in the vicinity of the Tagus estuary, and the eastern Gulf of Cadiz.

Egg spatial distribution was patchy and variable across years (Fig. 2 and supplementary material). Generally, the southern area showed higher egg abundance values. Low egg densities were observed over the entire study area in 2005 and 2010. In 2006, high abundances were observed but they were circumscribed to a couple of stations in the southern area. The wider egg distribution, with core areas over the northern shelf (on the Estremadura promontory just north of Lisbon), the southwestern coast and the inner Bay of Cadiz, was observed in 2008.

\section{Environmental descriptors}

Frequency distributions of environmental variables fluctuated over the years. The southern area generally showed higher salinity (between 35.5 and 36.3) and temperature values (between 13.9 and $18.8^{\circ} \mathrm{C}$ ) than the western coast (between 32.2 and 36.2 and between 
Table 1. - Information of the research cruises analysed in this study. Fishing stations were considered positive when total individuals was $>10$. Percentages in brackets are calculated in reference to the total number of fishing stations.

\begin{tabular}{|c|c|c|c|c|c|c|c|c|}
\hline Year & $\begin{array}{c}\text { Start of the } \\
\text { Survey }\end{array}$ & $\begin{array}{c}\text { End of the } \\
\text { Survey }\end{array}$ & $\begin{array}{l}\text { Effective survey } \\
\text { time (days) }\end{array}$ & $\begin{array}{l}\text { Fishing } \\
\text { stations }\end{array}$ & $\begin{array}{l}\text { Sardine-positive } \\
\text { fishing stations }\end{array}$ & $\begin{array}{l}\text { Juveniles-positive } \\
\text { fishing stations }\end{array}$ & $\begin{array}{l}\text { Number juve- } \\
\text { niles (million) }\end{array}$ & $\begin{array}{l}\text { Biomass juveniles } \\
\text { (thousand tonnes) }\end{array}$ \\
\hline 2005 & $08 / 04$ & $10 / 05$ & 28 & 41 & $23(56 \%)$ & $18(44 \%)$ & 19211 & 341 \\
\hline 2006 & $07 / 04$ & $05 / 05$ & 31 & 40 & $28(68 \%)$ & $15(38 \%)$ & 3836 & 102 \\
\hline 2007 & $13 / 04$ & $07 / 05$ & 28 & 48 & $31(65 \%)$ & $13(27 \%)$ & 665 & 18 \\
\hline 2008 & $01 / 04$ & $03 / 05$ & 30 & 49 & $32(65 \%)$ & $11(22 \%)$ & 842 & 11 \\
\hline 2009 & $31 / 03$ & $23 / 04$ & 30 & 35 & $25(71 \%)$ & $23(66 \%)$ & 7074 & 102 \\
\hline 2010 & $08 / 04$ & $05 / 05$ & 30 & 26 & $16(62 \%)$ & $10(38 \%)$ & 4901 & 94 \\
\hline
\end{tabular}

Table 2. - Summary of the presence models (presence $>10$ individuals). J, presence of juveniles; lat, latitude; lon, longitude; e, egg abundance. $\mathrm{N}$, samples with >10 individuals; Dev, deviance explained; $\mathrm{s}($ ) denotes that a smoother was used; te( ) denotes that a tensor was used.

\begin{tabular}{lcccccc}
\hline Area & $\mathrm{N}$ & Model & d.f. & UBRE score & AIC & Dev $(\%)$ \\
\hline West & 297 & j te(lat*lon)+s(e) & 14.5 & -0.13348 & 245.75 & 40.0 \\
South & 188 & j te(lat*lon)+s(e) & 11.7 & 0.25666 & 139.75 & 39.4 \\
\hline
\end{tabular}

$12.3^{\circ} \mathrm{C}$ and $17^{\circ} \mathrm{C}$, respectively; Fig. 2 and supplementary material), whereas fluorescence and zooplankton volume showed no consistent differences between areas. In 2010, a wider range of values was observed in salinity (32.0-36.1 in the southern and 32.6-36.3 in the western area), temperature $\left(17.3-19.0^{\circ} \mathrm{C}\right.$ in the southern and $14.1-17.4^{\circ} \mathrm{C}$ in the western area) and zooplankton volume (mean $3.402 \mathrm{ml} / 10 \mathrm{~m}^{3}$ in the southern and $3.607 \mathrm{ml} / 10 \mathrm{~m}^{3}$ in the western area), with generally
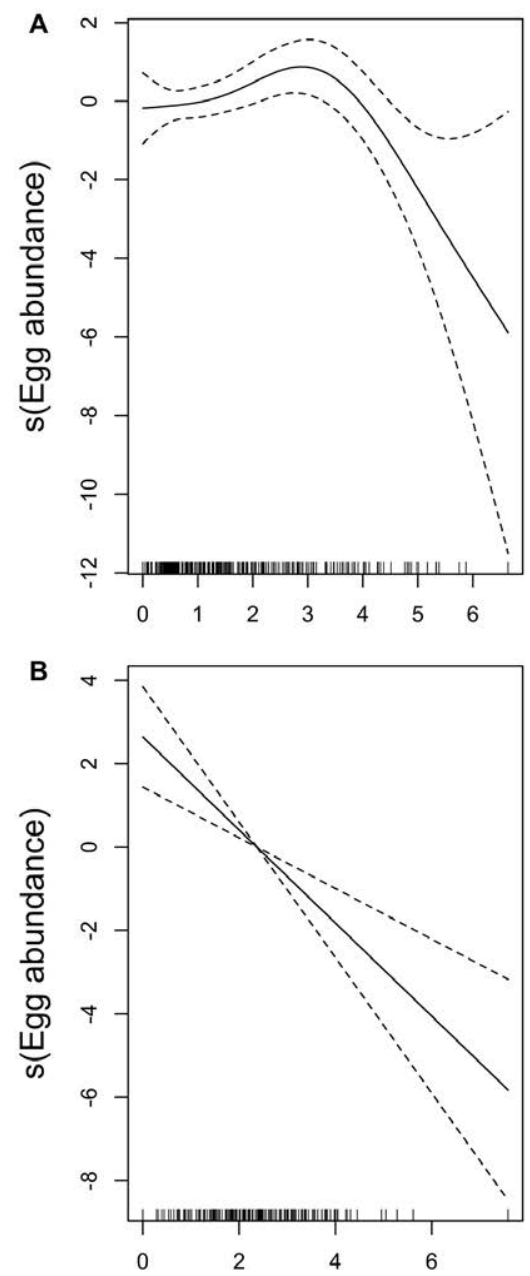

Egg abundance lower salinity and higher temperature and zooplankton volumes than in the previous years.

\section{Juvenile presence in relation to spawning grounds}

The best model for juvenile presence in both areas was defined by the interaction of geographical variables plus egg abundance (Table 2). In the western area, the best model showed that the probability of juvenile


Fig. 3. - Effects of egg distribution and geographic variables on presence of sardine juveniles in the western (A) and southern (B) area. 
Table 3. - Summary of the abundance models. N, number of samples; sal, salinity; t, temperature; f, fluorescence; z, zooplankton volume; lat, latitude; lon, longitude; Dev, deviance explained; s( ) denotes that a smoother was used. $\mathrm{W}_{1}$ and $\mathrm{s}_{1}$ are the models fitted with environmental variables only; $\mathrm{w}_{2}$ and $\mathrm{s}_{2}$ are the best models with environmental variables only and $\mathrm{w}_{3}$ and $\mathrm{s}_{3}$ are the models including geographical variables. In bold, the models plotted in Fig. 4.

\begin{tabular}{|c|c|c|c|c|c|c|c|}
\hline Area & $\mathrm{N}$ & Model & Terms & d.f & REML & AIC & $\operatorname{Dev}(\%)$ \\
\hline \multirow{4}{*}{ West } & \multirow{3}{*}{299} & $\mathrm{w}_{1}$ & $\mathrm{n} \sim \mathrm{s}(\mathrm{sal})+\mathrm{s}(\mathrm{t})+\mathrm{s}(\mathrm{f})+\mathrm{s}(\mathrm{z})$ & 12.14 & 1973.4 & 3941.68 & 28.5 \\
\hline & & $\mathrm{w}_{2}$ & $\mathrm{n} \sim \mathrm{s}(\mathrm{sal})+\mathrm{s}(\mathrm{t})+\mathrm{f}$ & 9.93 & 1972.974 & 3941.24 & 27.5 \\
\hline & & $\mathbf{w}_{\mathbf{3}}$ & $\mathrm{n} \sim s(\mathrm{sal})+s(\mathrm{t})+s(\mathrm{lat})$ & 17.27 & 1942.41 & 3862.571 & 44.6 \\
\hline & \multirow{3}{*}{190} & $\mathrm{~s}_{1}$ & $\mathrm{n} \sim \mathrm{s}(\mathrm{sal})+\mathrm{s}(\mathrm{t})+\mathrm{s}(\mathrm{f})+\mathrm{s}(\mathrm{z})$ & 8.01 & 929.99 & 1858.362 & 36.1 \\
\hline \multirow{2}{*}{ South } & & $\mathrm{S}_{2}$ & $\mathrm{n} \sim \mathrm{s}(\mathrm{f})+\mathrm{t}+\mathrm{z}$ & 5.85 & 928.89 & 1856.647 & 35.0 \\
\hline & & $\mathbf{s}_{3}$ & $n \sim s($ lon $)+t+z$ & 6.97 & 919.93 & 1834.691 & 41.8 \\
\hline
\end{tabular}

presence increases slightly with low levels of egg abundance and decreases sharply after an intermediate level of egg abundance (Fig. 3A). Geographic variables assisted in the identification of two zones of higher probability for juvenile presence: one in the region between Figueira da Foz and Aveiro $\left(\sim 40-41^{\circ} \mathrm{N}\right)$ and one at the Estremadura promontory $\left(\sim 39^{\circ} \mathrm{N}\right)$ (Fig. 3A). In the southern area, presence of juveniles is expected to decline linearly with egg abundance (coefficient [se]=1.07 [0.24]) (Fig. 3B). The best model for this area also evidenced the high probability of juvenile presence in the south except in the northwest and southeast corners (i.e. Cape São Vicente and at the entrance to the Strait of Gibraltar, respectively).

\section{Environmental and geographical effects on juvenile abundance}

GAM models were first fitted to both coasts considering just the environmental variables $\left(\mathrm{w}_{1} / \mathrm{w}_{2}\right.$ and $\mathrm{s}_{1} /$ $\mathrm{s}_{2}$ models; Table 3); however, models including geographic variables provided a significantly better fit to the juvenile abundance data and were selected as the final abundance models ( $\mathrm{w}_{3}$ and $\mathrm{s}_{3}$; Table 3 ).

The first model fitted to the west coast $\left(\mathrm{w}_{1}\right)$ explained $28.5 \%$ of the total deviance and included all the environmental variables: salinity, temperature, fluorescence and zooplankton volume. Model $\mathrm{w}_{2}$ explained $27.5 \%$ of the deviance and included dome-shaped
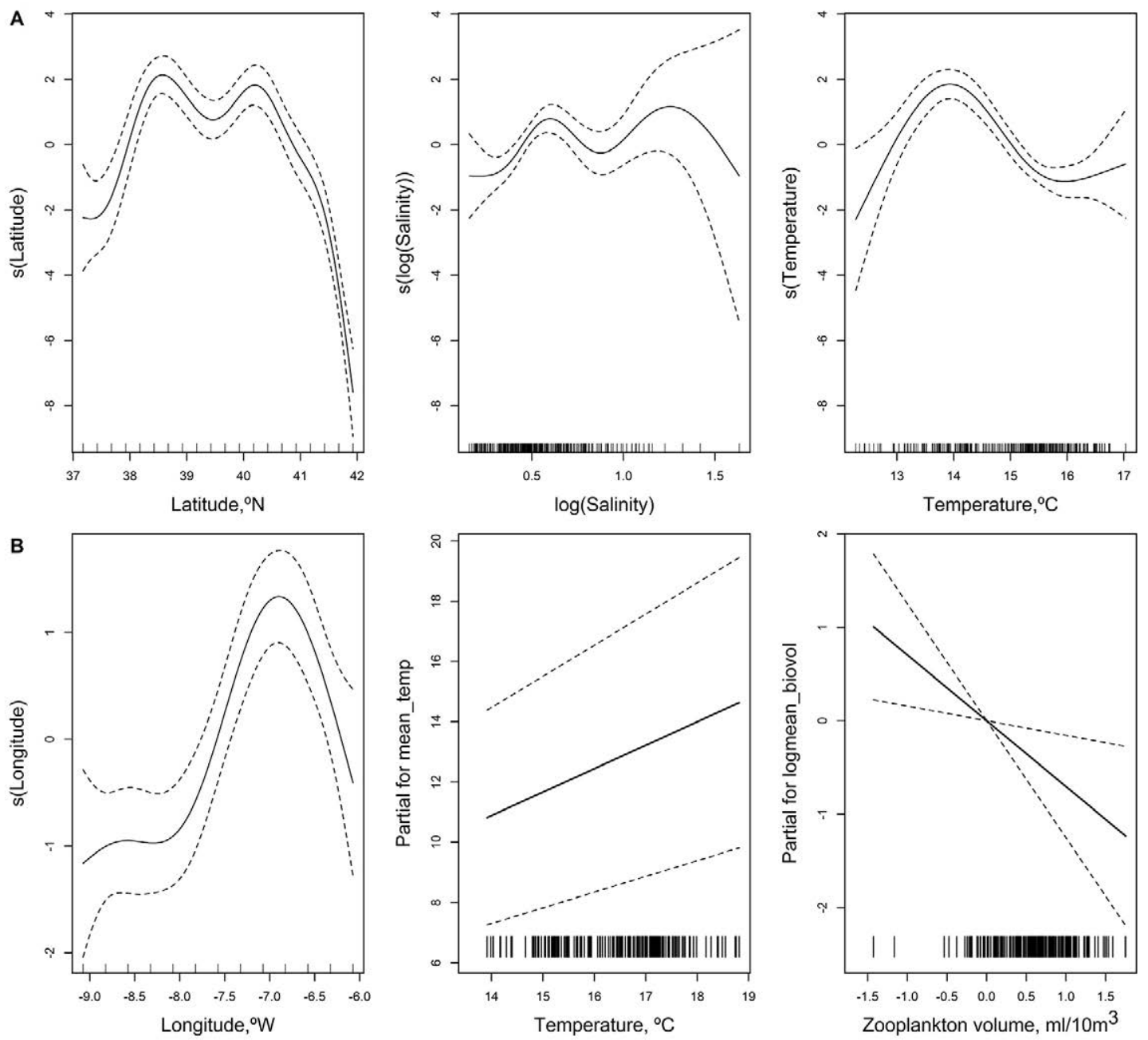

Fig. 4. - Effects of environmental and geographic variables on abundance of sardine juveniles in the western (A) and southern (B) area. 


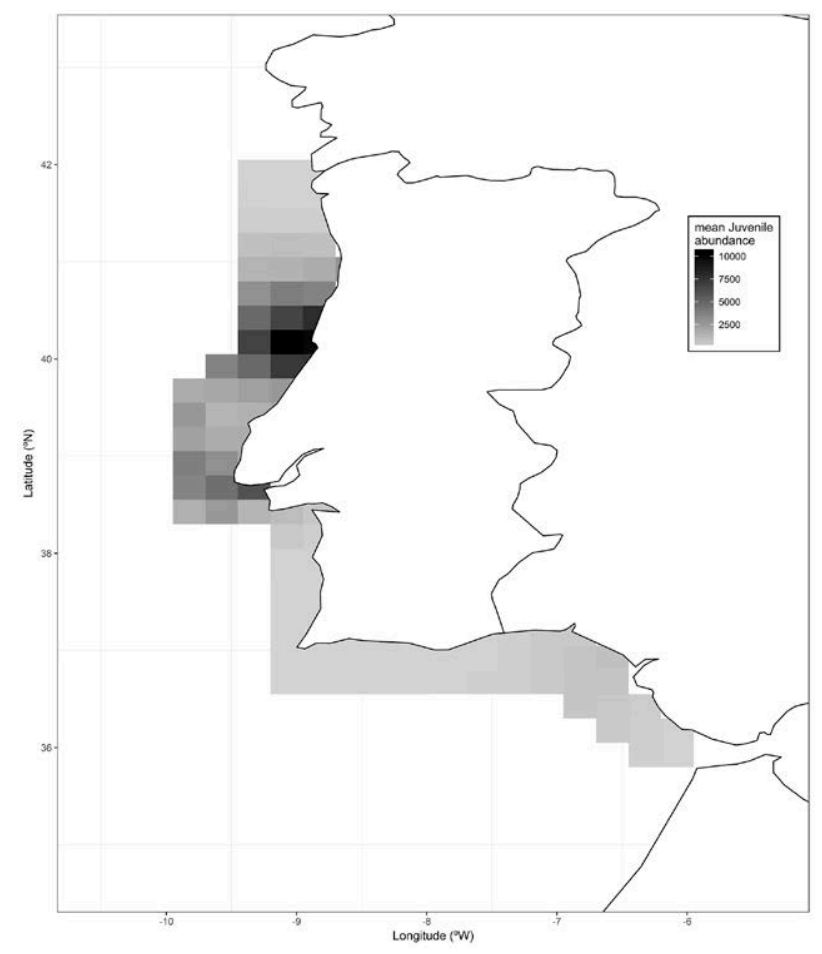

Fig. 5. - Predicted abundance of sardine juveniles from the GAM abundance models in the western and southern areas. Mean values for the years 2005-2009 are shown.

smooth functions of salinity and temperature, a positive linear effect of fluorescence (coefficient[se] $=1.6$ [0.28]) and dropped out the zooplankton term. The best model for the western area explained $44.6 \%$ of the total deviance $\left(\mathrm{w}_{3}\right.$, Table 3$)$. This model includes a domeshaped smoother function of temperature with a peak around $14^{\circ} \mathrm{C}$ (Fig. 4A) and a smooth effect of salinity with two domes $(\sim 35.3$ and $\sim 33.7)$. The latter peak in the salinity term showed a wider confidence interval due to sparse data. Juvenile abundance in this area also showed a bimodal shape response with latitude, displaying one peak at $\sim 38.6^{\circ} \mathrm{N}$ (Lisbon) and another one at $\sim 40.3^{\circ} \mathrm{N}$ (Figueira da Foz-Aveiro).

In the south, the first fitted model $\left(\mathrm{s}_{1}\right)$, contained all environmental terms and explained $36.1 \%$ of the total deviance. Model $\mathrm{s}_{2}$ included a dome-shaped smooth effect of fluorescence with a peak around $0.25 \mathrm{~V}$, a positive linear effect of temperature (coefficient[se]=1.1[0.14]) and a negative linear effect of zooplankton volume (coefficient[se]=1.5[0.29]) and explained $35 \%$ of the total deviance. In the southern area, the best model explained $41.8 \%$ of the total deviance $\left(s_{3}\right.$, Table 3$)$. Model $s_{3}$ indicates a linear increase of juvenile abundance with temperature (coefficient [se] $=0.78[0.13]$ ) and a linear decrease with zooplankton volume (coefficient[se] $=-0.70[0.27]$ ). Longitude, representing the alongshore location, helped to identify a peak of juveniles around $6.6^{\circ} \mathrm{W}$ (Huelva, Fig. 4B).

GAM mean values (years 2005-2009) of predicted abundance of sardine juveniles for both areas (Fig. 5 and supplementary material) highlighted three core areas: the northern Portuguese shelf (centred off Aveiro), the coastal region in the vicinity of the Tejo estuary and, with slightly less predominance, the eastern Gulf of Cadiz (between Tinto and Odiel estuary and Guadalquivir estuary).

\section{DISCUSSION}

In most cases, areas with high levels of sardine juvenile did not match spawning grounds (areas with the highest egg concentrations), as reported for eggs and larvae (Santos et al. 2004). From the three core-zones in this study, only the Gulf of Cadiz region corresponds to an area of significant spawning preference evidenced by Bernal et al. (2007); however this is also the corezone where the lowest values of juveniles were found. Nevertheless, the outcomes of the present study highlight that intermediate egg abundances values foster juvenile sardine presence. Therefore, the aforementioned mismatch may reflect different levels of survival (or mortality), transport and/or movement of larvae and/or young juveniles, or even methodological issues.

Several oceanographic processes have been reported to influence survival of fish in their first life stages (i.e. larvae and juvenile individuals) after egg hatching (Katara 2014). In the western area, the presence of the Western Iberian Buoyant Plume (WIBP; Peliz et al. 2002) that transports lower salinity water from river discharge to offshore, allows for the growth and concentration of phytoplankton during winter, which coincides with the spawning season (Peliz and Fiúza 1999), and favours larval survival (Santos et al. 2007). Also, the hypothesis of cannibalism should not be dismissed, as sardine species have been reported to cannibalize their own eggs and larvae (Garrido and van der Lingen 2014).

A mismatch between distribution of eggs and adults has also been reported for some areas (Bernal et al. 2007, ICES 2016), and may indicate displacement of fish, larvae and/or eggs. The Iberian Poleward Current (IPC), a narrow (25-40 km), slope-trapped, tongue-like structure that flows northerly off the coasts of the Iberian Peninsula and the South of France (de Castro et al. 2011), creates favourable conditions for the retention of larvae close to the shelf break (Santos et al. 2007). In fact, it is the combination of the two structures, the WIBP (acting vertically) and the IPC (acting horizontally), that counteracts the upwelling event present in this area, creating a convergent band where eggs and larvae are retained (Santos et al. 2004). Therefore, it is likely that sardine juveniles migrate to coastal areas by both passive and active transport processes, while advection processes facilitate the passive transport of sardine eggs (although limited since their longevity is usually short, less than 4 days). This has been previously pointed out for other fish species in the same study areas, such as Solea solea (L., 1758), where spawning grounds differ from nursery pools (Koutsikopoulos and Lacroix 1992).

Another hypothesis to explain the eggs-juveniles mismatch is a different habitat use. Spatial differences between juvenile presence and egg abundances suggest that essential juvenile habitat might differ from essential spawner habitat. Spawning areas are com- 
monly characterized by productivity-inducing oceanic processes such as upwelling and riverine plumes (Bergeron 2004), and current systems that lead eggs, larvae and their prey to appropriate nursery areas (Cotano et al., 2008). On the other hand, nursery grounds are in general retention areas (Katara 2014). In addition, Portugal's coastal geomorphology may favour the presence of eggs and not juveniles. The narrow ( 25 $\mathrm{km})$, rocky and steep continental shelf with little influence from river runoffs (Zwolinski et al. 2010) might explain the juveniles' avoidance of this area. This has also been demonstrated for the Mediterranean, where preferred spawning grounds tend to be restricted and associated with nutrient enrichment point sources that enhance productivity, such as river runoffs or local upwelling (Giannoulaki et al. 2011). This might explain why Costa Vicentina (from the Sado River to Cape São Vicente, Fig. 1) showed higher egg abundance than juvenile abundance (see supplementary material) and why the western coast shows lower levels of sardine adults (Zwolinski et al. 2010).

Finally, some methodological issues might explain the observed mismatch. Ichthyoplankton surveys have shown that sardine spawning is restricted to the continental shelf (Ré et al. 1990), and sardine juveniles are known to aggregate in shallow areas. This may lower the accessibility of fish when compared with accessibility of eggs in acoustic surveys (i.e. distribution of shoals very close to coast or to the bottom and topographic features may lower the probability of detection).

The results indicate that waters with lower salinity and temperature values favour the abundance of juveniles on the Portuguese western coast. When associated with high fluorescence levels and zooplankton concentrations, these waters may indicate the existence of river discharges (i.e. freshwater enrichment). Higher-discharge rivers (the Minho, Douro, Mondego and Vouga in the northern area, the Tejo and Sado in the Lisbon area and the Guadiana, Tinto, Odiel and Guadalquivir in the Gulf of Cadiz region) located along the two study areas (Fig. 1) create significant productive estuarine zones (Silva et al. 2009). Estuarine zones have been long recognized as important nursery areas (McLusky 1989). This derives from their oceanographic features, which, combined with optimal environmental windows, offer fish species in the first years of life with high food availability, refuge from predators, and physical protection. Along the Portuguese coast and the Gulf of Cadiz, the importance of these estuarine systems as nursery areas has also been highlighted (Vasconcelos et al. 2010). For instance, in the Guadalquivir estuary, young stages of European anchovy (Engraulis encrasicolus (L., 1758)) and sardine represented $94 \%$ of all collected individuals in a study analysing the effects of estuarine fisheries on the recruitment of fish (Sobrino et al. 2005). These results are in agreement with Zwolinski et al. (2010), who found that higher concentrations of chlorophyll $a$, low salinity and either high or low temperatures lead to higher presence of sardine adults off the western coast. However, they contrast with what was observed for the eastern Mediterranean and the Bay of Biscay. In the former case, sardines were associated with warmer waters (Giannoulaki et al. 2011), while in the latter no preferences were observed in relation to hydrographic conditions (Petitgas et al. 2006).

Topography is suggested to play an important role in directing local distribution and variability of EFH. The areas of higher probability of juvenile presence were located in coastal shallow zones $\left(40-41^{\circ} \mathrm{N}\right.$ and $9^{\circ} \mathrm{W} \sim$ Aveiro and $38^{\circ} \mathrm{N}$ and $9.6^{\circ} \mathrm{W} \sim$ south of Sado River in the west; area covering the Gulf of Cadiz in the south), similarly to what is found in the Mediterranean Sea. In this area, suitable sardine nursery areas are presumably located in shallow coastal waters (up to $100 \mathrm{~m} \mathrm{depth)}$ in the north of the Alboran Sea, the Sicily Strait, the western coast of the Italian Peninsula, and the Cretan Shelf in Greek seas, and areas along the Levantine coast (, and the Cretan Shelf in Greek seas, and areas along the Levantine coast (Bellido et al. 2008, Giannoulaki et al. 2011). This reinforces the hypothesis of juveniles' preference for areas with plenty of food and physical protection.

GAM abundance results further indicate that, although different in intensity, similar factors are associated with the sardine's ontogeny off the western coast. This suggests an equivalent ecological niche: both sardine adults (Zwonlinski et al. 2010) and juveniles seem to prefer environmental conditions characteristic of freshwater enrichments. In the southern area, high temperature and low zooplankton volumes combined with longitude explained higher juvenile abundance. As no GAM models for adult distribution in relation to environmental factors have been constructed for the southern area, we have no source of comparison available. However, the extent data set of acoustic spring surveys collected by the institute in the last 32 years reveals that the Gulf of Cadiz is an area prone to high adult sardine concentrations (Marques 2005, ICES 2016).

The differences in factors contributing to juvenile distribution between areas are probably due to coastline orientation, which in turn causes differences in physical forcing, such as winds and currents (Ré et al. 1990, Relvas and Barton 2002, Santos et al. 2004). As suggested for egg abundance, the persistent higher abundance of juveniles found in this study (first in the western area and one year later in the southern area) might suggest movement of juveniles towards the south, hypothetically facilitated by oceanic processes (Santos et al. 2004, 2007).

The three core areas of juvenile abundance found in this study seem to be persistent in time, as was highlighted by Marques (2005) in prior annual surveys. Similarly, studies using area aggregated data from acoustic surveys and commercial catches suggested that the abovementioned zones are more prolific for the abundance of juvenile sardine, designating them as recruitment "hotspots" (Silva et al. 2009). It has been proved that small pelagic fish such as sardines are most likely to have more confined distribution to their suitable habitat at low affluences (MacCall 1990). The lower prevalence of juveniles in the south 
area (Gulf of Cadiz) in the present study compared with earlier periods (e.g. Marques 2005) reflects the decrease in abundance and recruitment of sardine in the area (ICES 2016).

The protection of essential fish habitat by means of marine protected areas (MPAs) might improve the current status of both habitats and stocks, and ensure the long-term sustainability of fisheries resources (Giannoulaki et al. 2011). However, given the complexity of the processes within marine ecosystems, the ecological changes that an MPA creation might bring about vary greatly from one region to another and are difficult to predict accurately (Edgar et al. 2007). The outcomes of the present study may assist in the identification of areas where the protection of juveniles is imperative, but more studies to analyse the impacts on the entire ecosystem are recommended.

This study has shed light on the relationship between environmental and geographical variables and the distribution of sardine juveniles along the Portuguese coast and the Gulf of Cadiz. Habitat modelling, as in the work presented here, provides essential information for identifying priority areas for the effective management of the sardine stock in the Iberian Peninsula.

\section{ACKNOWLEDGEMENTS}

This manuscript was first presented as a draft work in a poster in the "The Johan Hjort Symposium on Recruitment Dynamics and Stock Variability" held in Bergen, Norway 7-9 October, 2014. The IPMA (Instituto Português do Mar e da Atmosfera) acoustic surveys were undertaken within the Plano Nacional de Amostragem Biológica (PNAB) co-financed by the EU-Data Collection Framework. The work of S. Rodríguez-Climent was supported by CERTIFICA (Certificação MSC em Portugal: obtenção de conhecimento e estudos de viabilidade para candidaturas de pescarias costeiras e artesanais. Ref 31-03-01-FEP-0032; PROMAR). The $\mathrm{R}$ script for the gridding procedures was developed by Pierre Petitgas and made available via the WGACEGG.

\section{REFERENCES}

Bellido J.M., Brown A.M., Valavanis V.D., et al. 2008. Identifying essential fish habitat for small pelagic species in Spanish Mediterranean waters. Hydrobiology 612: 171-184. https://doi.org/10.1007/s10750-008-9481-2

Bergeron J.P. 2004. Contrasting years in the Gironde estuary (Bay of Biscay, NE Atlantic) springtime outflow and consequences for zooplankton pyruvate kinase activity and the nutritional condition of anchovy larvae: An early view. ICES J. Mar. Sci. 61: 928-932.

https://doi.org/10.1016/j.icesjms.2004.06.019

Bernal M., Stratoudakis Y., Coombs S., et al. 2007. Sardine spawning off the European Atlantic coast: Characterization of and spatio-temporal variability in spawning habitat. Prog. Oceanogr. 74: 210-227. https://doi.org/10.1016/j.pocean.2007.04.018

Cotano U., Irigoien X., Etxebeste E., et al. 2008. Distribution, growth and survival of anchovy larvae (Engraulis encrasicolus L.) in relation to hydrodynamic and trophic environment in the Bay of Biscay. J. Plankton Res. 30: 467-481. https://doi.org/10.1093/plankt/fbn011

De Castro M., Gómez-Gesteira M., Álvarez I., et al. 2011. Atmos- pheric modes influence on Iberian Poleward Current variability. Cont. Shelf Res. 31: 425-432.

https://doi.org/10.1016/j.csr.2010.03.004

Doray M. 2013. EchoR package tutorial. 10 pp

Edgar G.J., Russ G.R., Babcock R.C. 2007. Marine protected areas. In: Connell B.M., Sean D. (eds) Marine Ecology. Oxford Univ. Press, pp. 533-555.

Foote K., Knudsen H., Vestnes G., et al. 1987. Calibration of acoustic instruments for fish density estimation: a practical guide. ICES Coop Res Rep. No 144. 81 pp.

Garrido S., van der Lingen C. 2014. Feeding Biology and Ecology. In: Ganias K. (eds), Biology and Ecology of Sardines and Anchovies. Boca Raton, CRC Press, pp. 190-242. https://doi.org/10.1201/b16682-7

Giannoulaki M., Pyrounaki M.M., Liorzou B., et al. 2011. Habitat suitability modelling for sardine juveniles (Sardina pilchardus) in the Mediterranean Sea. Fish Oceanogr. 20: 367-382. https://doi.org/10.1111/j.1365-2419.2011.00590.x

ICES. 2016. Second Interim report of the Working Group on Acoustic and Egg Surveys for Sardine and Anchovy in ICES Areas VII, VIII and IX (WGACEGG), 16-20 November 2015. ICES CM 2015/SSGIEOM:31.

Katara I. 2014. Recruitment Variability. In: Ganias K. (eds), Biology and Ecology of Sardines and Anchovies. Boca Raton, CRC Press, pp. 242-285. https://doi.org/10.1201/b16682-9

Koutsikopoulos C., Lacroix N. 1992. Distribution and abundance of sole (Solea solea (L.)) eggs and larvae in the Bay of Biscay between 1986 and 1989. Neth. J. Sea Res. 29: 81-91. https://doi.org/10.1016/0077-7579(92)90009-4

Levin P.S., Stunz G.W. 2005. Habitat triage for exploited fishes: Can we identify essential 'Essential Fish Habitat?' Est. Coast. Shelf Sci. 64: 70-78. https://doi.org/10.1016/j.ecss.2005.02.007

MacCall A. 1990. Dynamic geography of marine fish populations.1st edn. Washington University Press, $153 \mathrm{pp}$.

Marques V. 2005. Campanhas Acústicas Portuguesas Dirigidas a Sardinha (Sardina pilchardus, Walb.) (1984-2003). Dissertação para provas de acesso à categoriade Investigador Auxiliar. Instituto nacional de Investigação das Pescas, $262 \mathrm{pp}$.

McLusky D.S. 1989. The Estuarine Ecosystem. 2nd ed. Chapman \& Hall. 215 pp.

Parrish R.H., Serra R., Grant W.S. 1989. The Monotypic Sardines, Sardina and Sardinops: Their Taxonomy, Distribution, Stock Structure, and Zoogeography. Can. J. Fish. Aquat. Sci. 46: 2019-2036. https://doi.org/10.1139/f89-251

Peliz A.J., Fiúza A.F.G. 1999. Temporal and spatial variability of CZCS-derived phytoplankton pigment concentrations off the western Iberian Peninsula. Int. J. Remote Sens. 20: 1363-1403. https://doi.org/10.1080/014311699212786

Peliz A., Rosa T.L., Santos M.P., et al. 2002. Fronts, jets, and counter-flows in the Western Iberian Upwelling system. J. Mar. Syst. 35: 61-77. https://doi.org/10.1016/S0924-7963(02)00076-3

Petitgas P., Masse J., Bourriau P., et al. 2006. Hydro-plankton characteristics and their relationship with sardine and anchovy distributions on the French shelf of the Bay of Biscay. Sci. Mar. 70S1: 161-172.

R Development Core Team. 2011. R: A Language and Environment for Statistical Computing. Foundation for Statistical Computing, Vienna, Austria, ISBN3-900051-07-0. http://www.R-project.org

Relvas P., Barton E.D. 2002. Mesoscale patterns in the Cape São Vicente (Iberian Peninsula) upwelling region. J. Geophys. Res. 107(C10): 3164 https://doi.org/10.1029/2000JC000456

Ré P., Silva C., Cunha E., et al. 1990. Sardine spawning off Portugal. Bol. Inst. Nac. Invest. Pescas 15: 31-44.

Santos A.M.P., Peliz A., Dubert J., et al. 2004. Impact of a winter upwelling event on the distribution and transport of sardine (Sardina pilchardus) eggs and larvae off western Iberia: A retention mechanism. Cont. Shelf Res. 24: 149-165. https://doi.org/10.1016/j.csr.2003.10.004

Santos A.M.P., Chícharo A., Dos Santos A., et al. 2007. Physicalbiological interactions in the life history of small pelagic fish in the Western Iberia Upwelling Ecosystem. Prog. Oceanogr. 74: 192-209.

https://doi.org/10.1016/j.pocean.2007.04.008

Silva A., Santos M., Caneco B., et al. 2006. Temporal and geo- 
graphic variability of sardine maturity at length in the northeastern Atlantic and the western Mediterranean. ICES J. Mar. Sci. 63: 663-676. https://doi.org/10.1016/j.icesjms.2006.01.005

Silva A., Skagen D.W., Uriarte A., et al. 2009. Geographic variability of sardine dynamics in the Iberian Biscay region. ICES J. Mar. Sci. 66: 495-508.

https://doi.org/10.1093/icesims/fsn225

Simmonds J., MacLennan D. 2005. Fisheries Acoustics. Theory and Practice. Blackwell Science Ltd. 456 pp. https://doi.org/10.1002/9780470995303

Sobrino I., Baldó F. García-González D., et al. 2005. The effect of estuarine fisheries on juvenile fish observed within the Guadalquivir Estuary (SW Spain). Fish. Res. 76: 229-242. https://doi.org/10.1016/j.fishres.2005.06.016

Valavanis V.D., Pierce G.J., Zuur A.F., et al. 2008. Modelling of essential fish habitat based on remote sensing, spatial analysis and GIS. Hydrobiologia 612: 5-20. https://doi.org/10.1007/s10750-008-9493-y

Vasconcelos R.P., Reis-Santos P., Maia A., et al. 2010. Nursery use patterns of commercially important marine fish species in estuarine systems along the Portuguese coast. Est. Coast. Shelf. Sci. 86: 613-624

https://doi.org/10.1016/j.ecss.2009.11.029

Weill A., Scalabrin C., Diner N. 1993. MOVIES-B: an acoustic detection description software. Application to shoal species' classification.

Whitehead P.J.P. 1985. FAO species catalogue. Vol. 7. Clupeoid fishes of the world. Annotated and illustrated catalogue of the herrings, sardines, pilchards, sprats, anchovies and wolfherrings. Part 1 - Chirocentridae, Clupeidae and Pristigasteridae. FAO Fisheries Synopsis 7, $303 \mathrm{pp}$.

Wood S.N. 2006. Generalized additive models: An introduction with R. Boca Raton, CRC Press. 391 pp.

Zwolinski J.P., Oliveira P.B., Quintino V., et al. 2010. Sardine potential habitat and environmental forcing off western Portugal. ICES J. Mar. Sci. 67: 1553-1564

https://doi.org/10.1093/icesjms/fsq068

\section{SUPPLEMENTARY MATERIAL}

The following supplementary material is available through the online version of this article and at the following link: http://scimar.icm.csic.es/scimar/supplm/sm04554esm.pdf

Fig. S1. - Spatial distribution maps of sea surface environmental variables and abundance of juveniles. 
Scientia Marina 81(3)

September 2017, S1-S7, Barcelona (Spain)

ISSN-L: 0214-8358

\section{Essential habitat for sardine juveniles in Iberian waters}

Sílvia Rodríguez-Climent, Maria Manuel Angélico, Vítor Marques, Paulo Oliveira, Laura Wise, Alexandra Silva

Supplementary material 


\section{A: salinity}
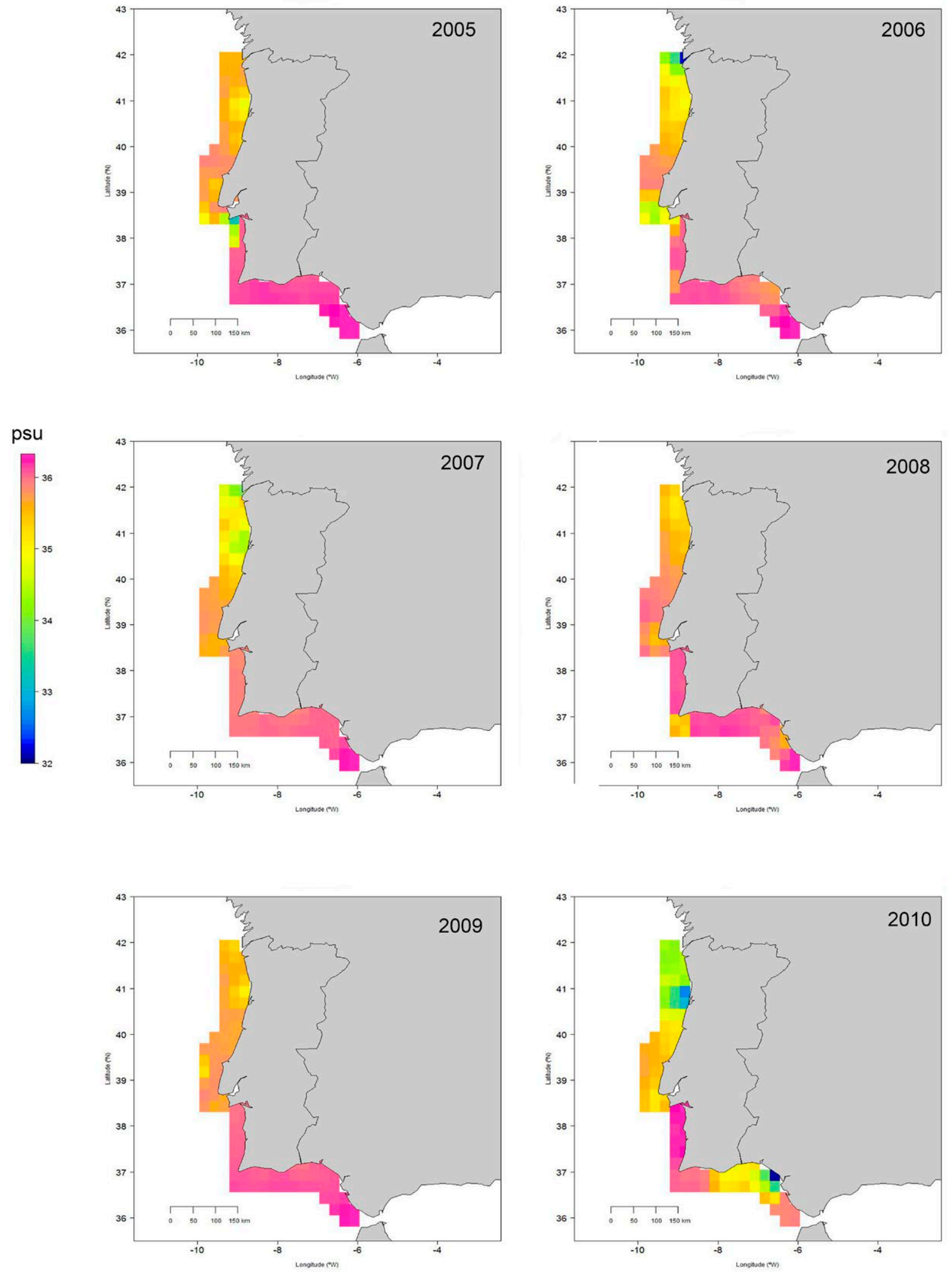

Fig. S1. - Spatial distribution maps of sea surface environmental variables and abundance of juveniles. 


\section{B: temperature}


${ }^{\circ} \mathrm{C}$
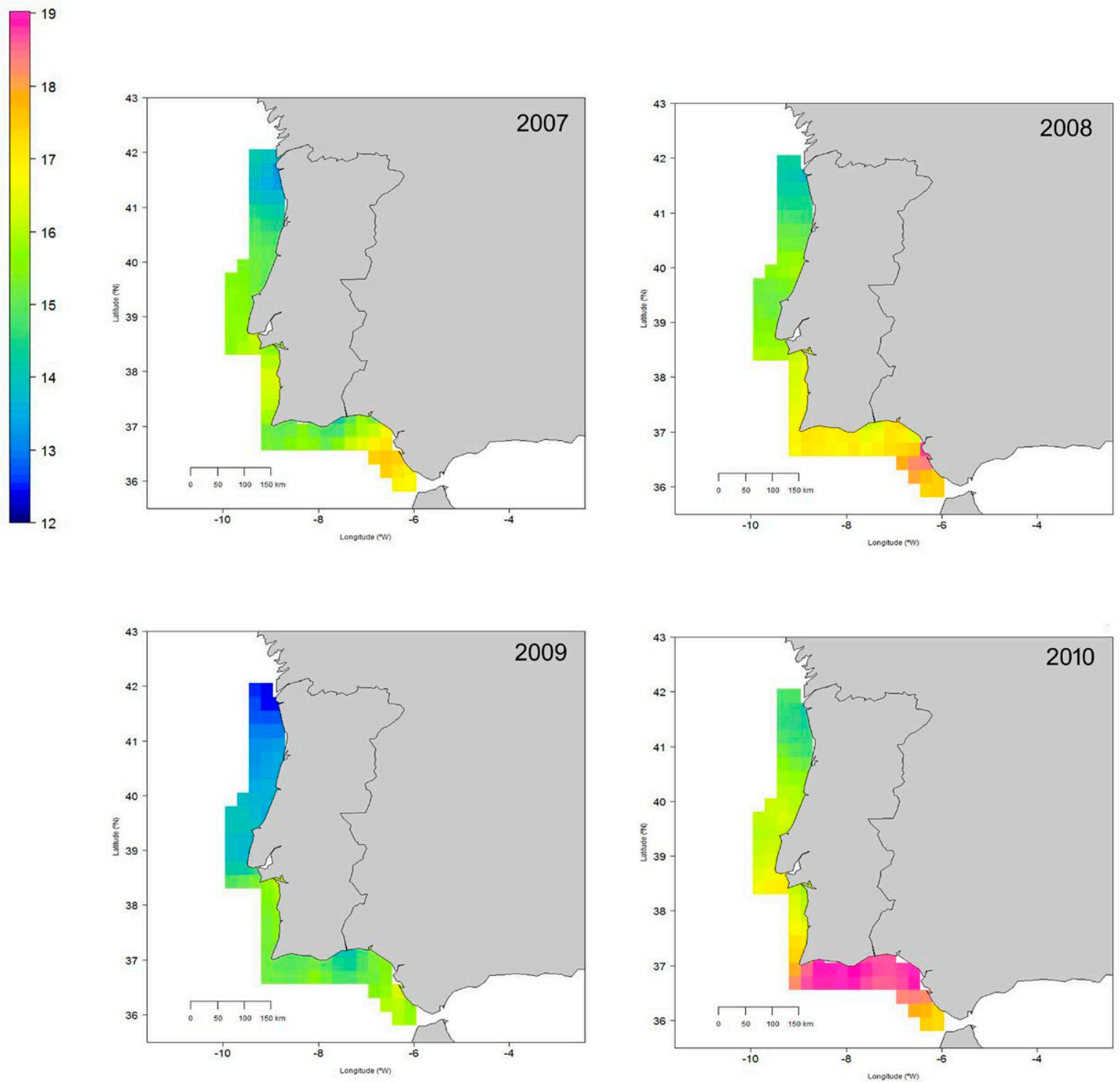

Fig. S1 (Cont.). - Spatial distribution maps of sea surface environmental variables and abundance of juveniles. 


\section{C: flourescence}
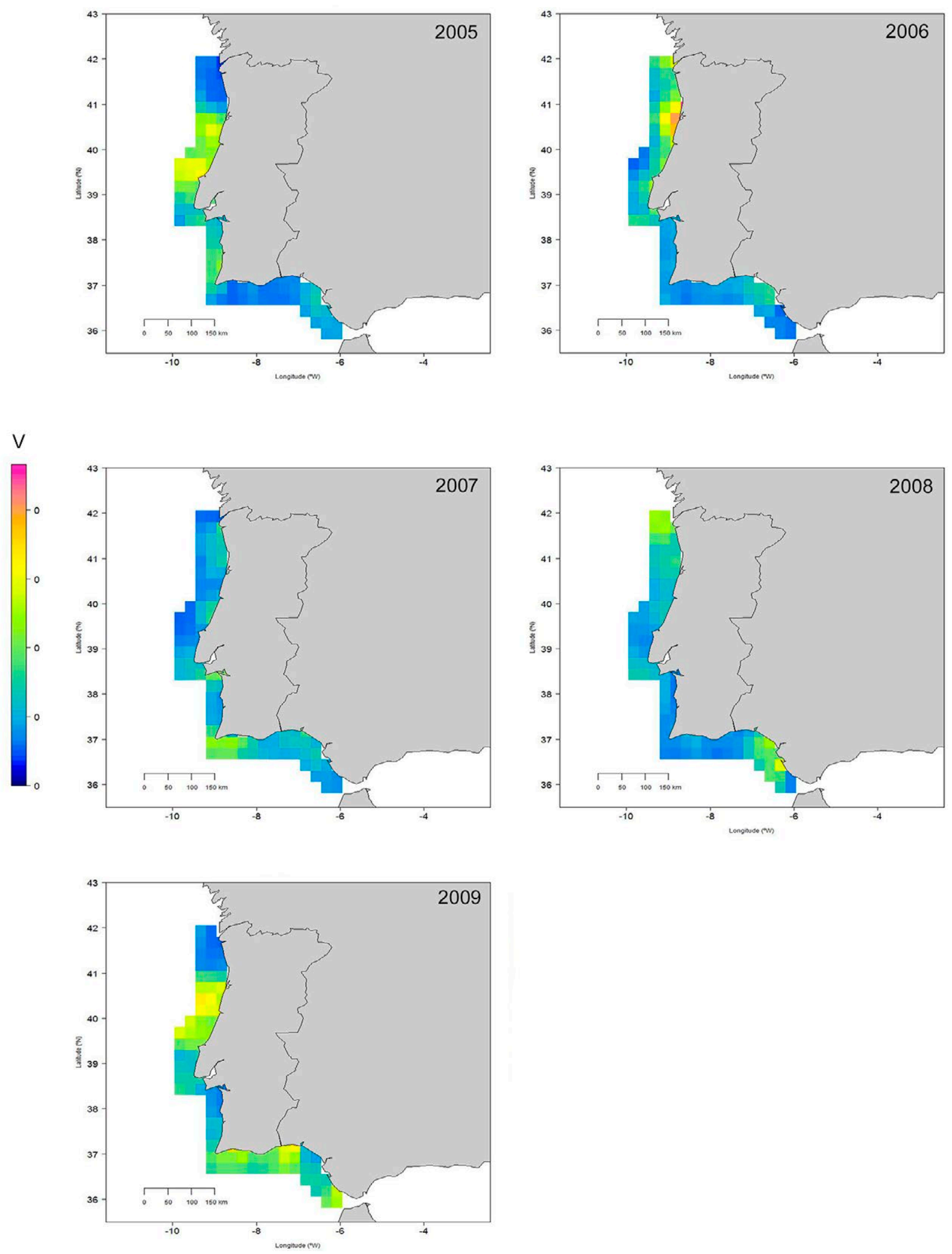

Fig. S1 (Cont.). - Spatial distribution maps of sea surface environmental variables and abundance of juveniles. 


\section{D: zooplankton volume}

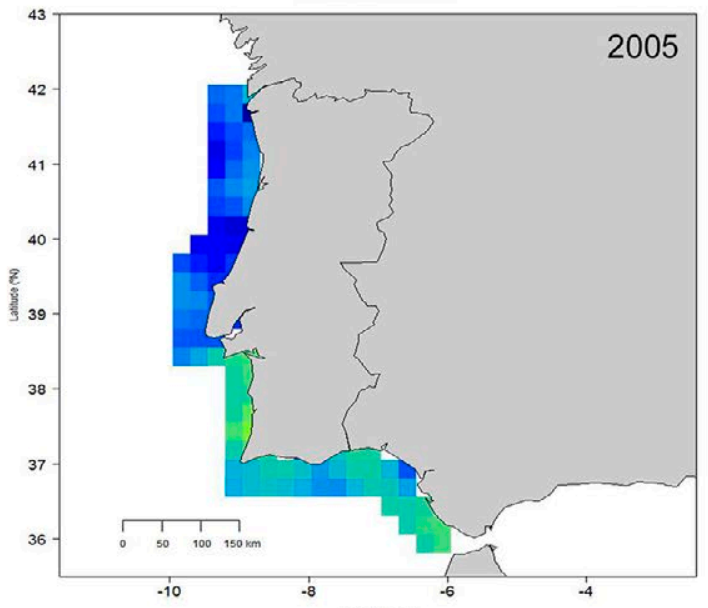

$\mathrm{ml} / 10 \mathrm{~m}^{3}$
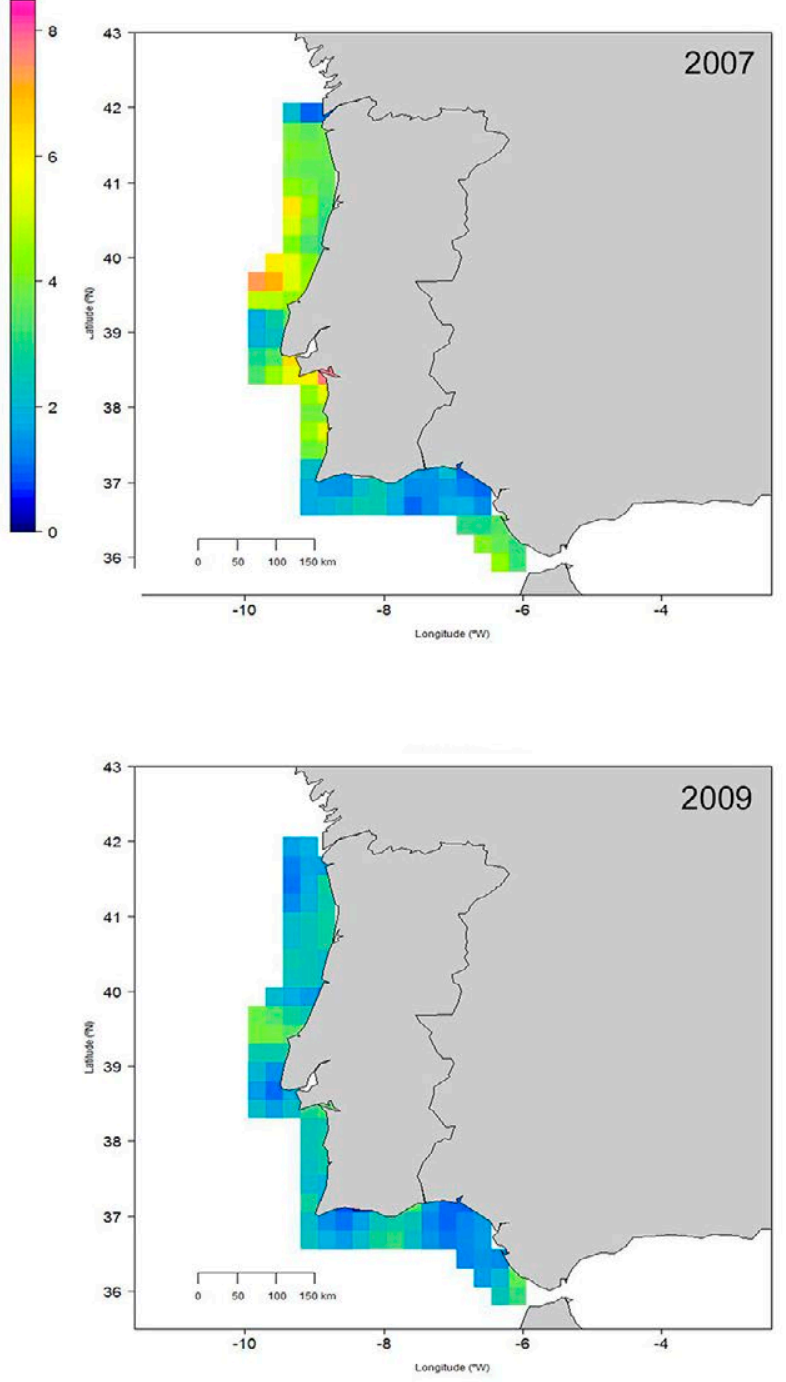
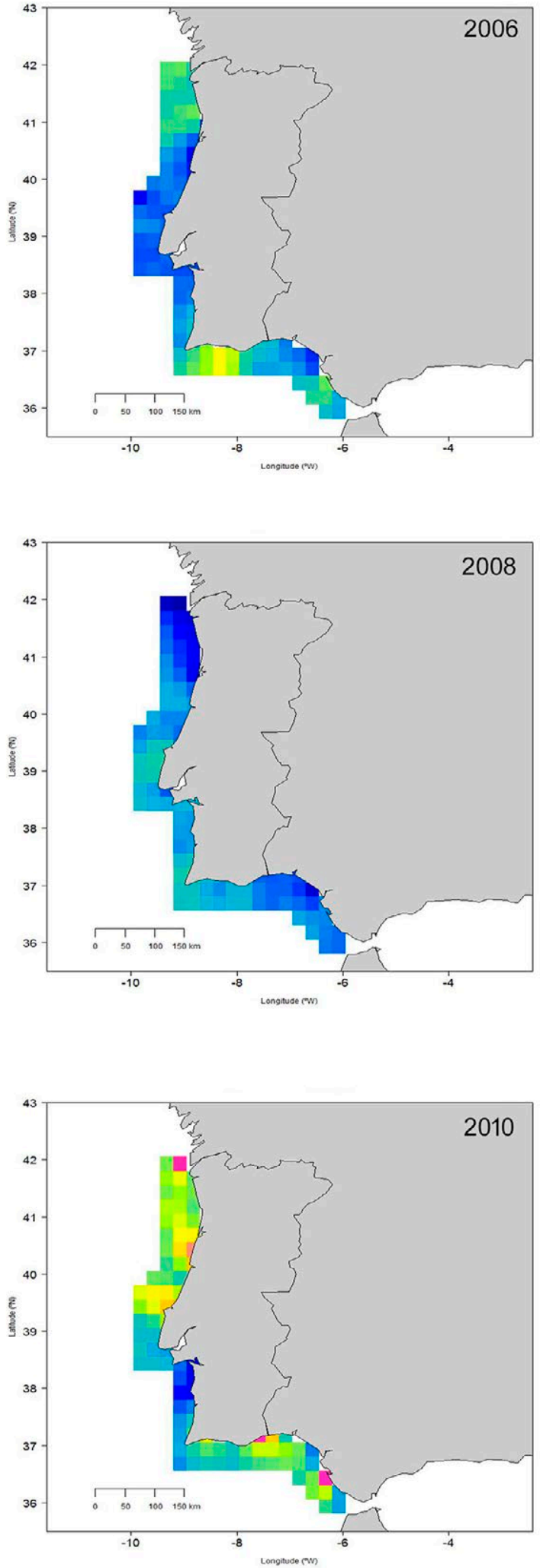

Fig. S1 (Cont.). - Spatial distribution maps of sea surface environmental variables and abundance of juveniles. 


\section{E. egg abundance}



number $/ \mathrm{m}^{3}$

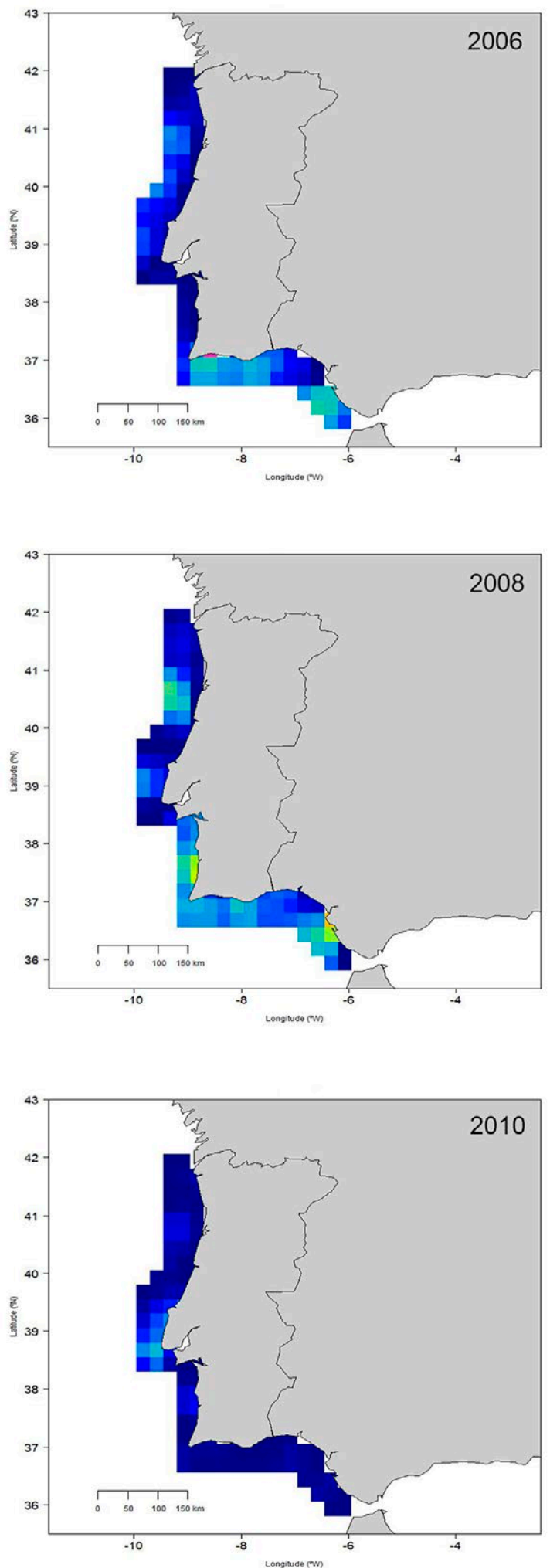

Fig. S1 (Cont.). - Spatial distribution maps of sea surface environmental variables and abundance of juveniles. 
F: juvenile abundance
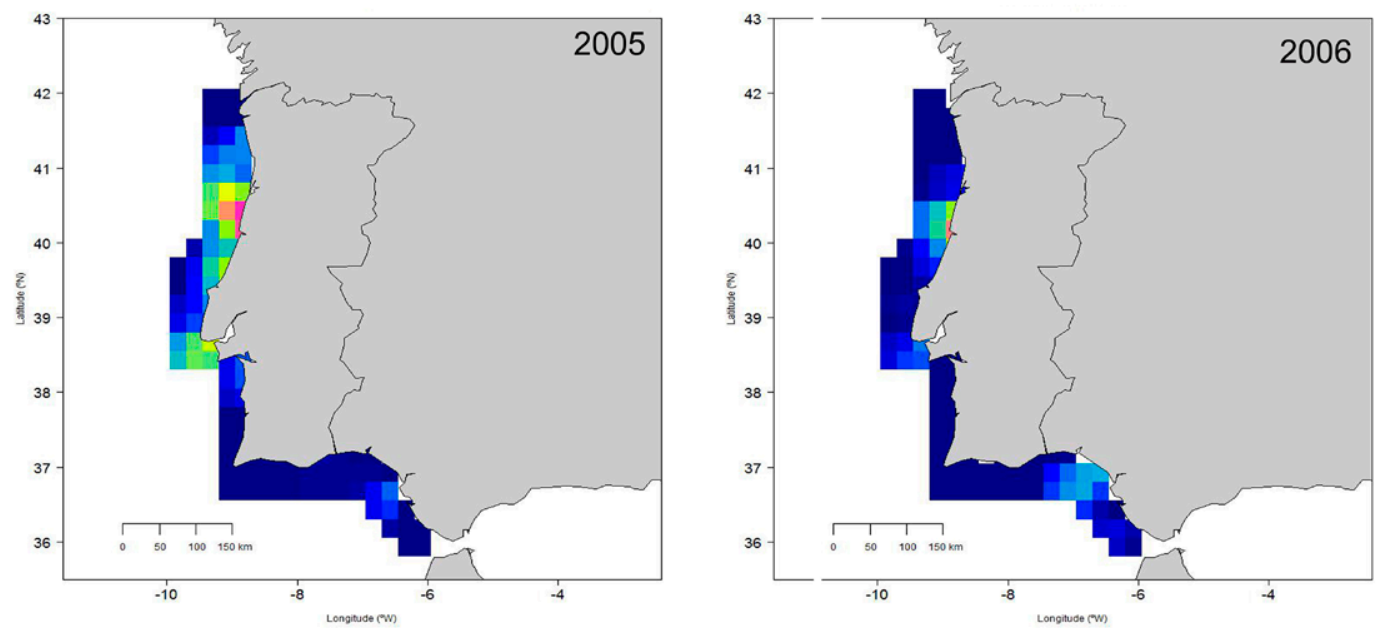

$\mathrm{t} / \mathrm{nm}$
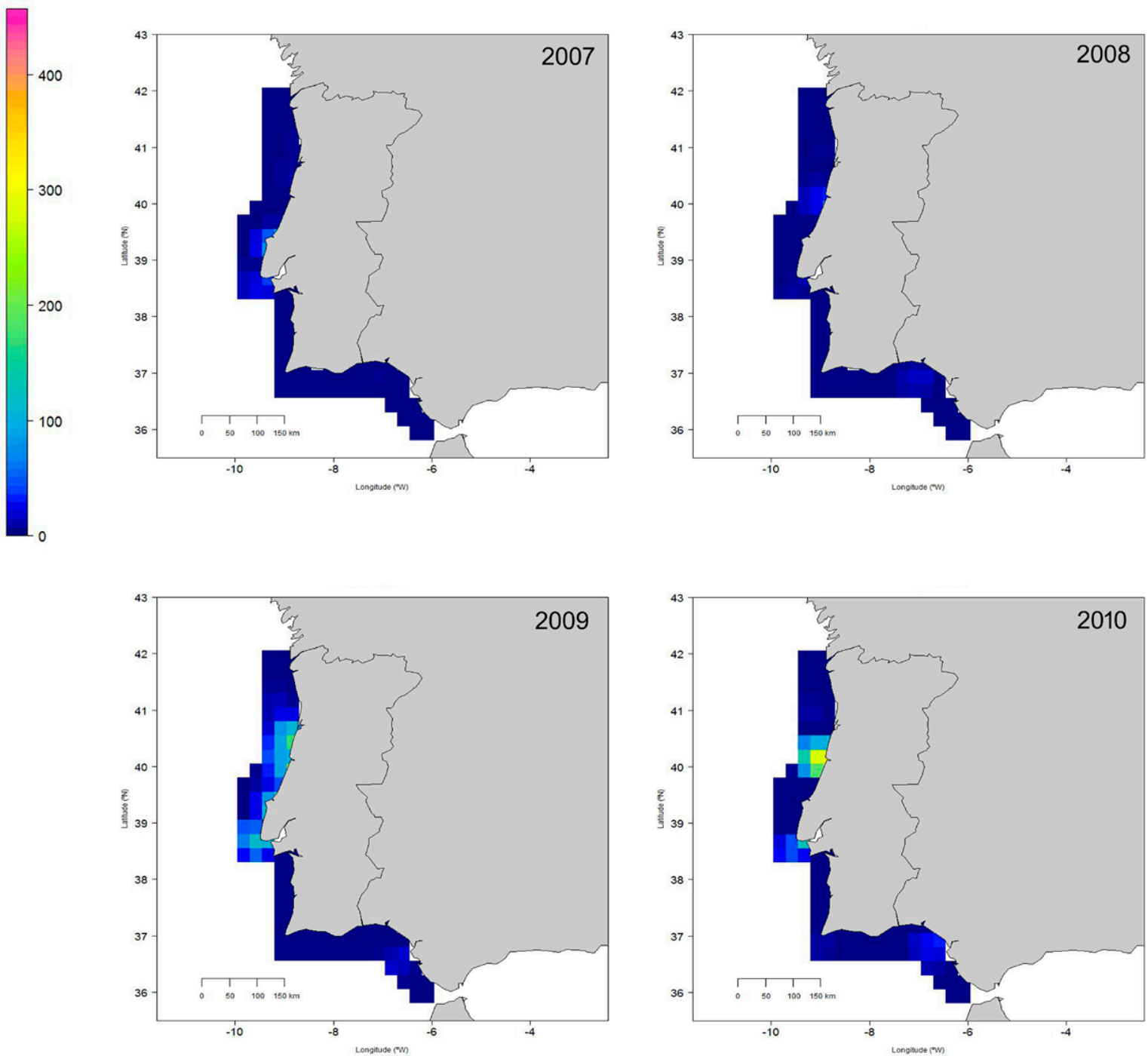

Fig. S1 (Cont.). - Spatial distribution maps of sea surface environmental variables and abundance of juveniles. 